Journal of Agrometeorology 23 (4) : 428-434 (December 2021) : https://doi.org/10.54386/jam.v23i4.148

\title{
Influence of weather factors, soil temperature and moisture on collar rot disease of betelvine (Piper betle L.) under coastal saline zone of West Bengal
}

\author{
PRABIR KUMAR GARAIN ${ }^{*}$, BHOLANATH MONDAL ${ }^{2}$ and SUBRATA DUTTA ${ }^{3}$ \\ ${ }^{1}$ Ramkrishna Ashram Krishi Vigyan Kendra, Nimpith, South 24 Parganas, India \\ ${ }^{2}$ Palli-Siksha Bhavana, Visva-Bharati, Sriniketan, India \\ ${ }^{3}$ Bidhan Chandra Krishi Viswavidyalaya, Mohanpur, India \\ *Corresponding author email : pkgarain79@gmail.com
}

\begin{abstract}
A study was conducted to find out the influence of weather factors, soil temperature and soil moisture on the incidence of Sclerotium rolfsii Sacc. induced collar rot disease in betelvine (Piper betle L.), during 2016 to 2018. Fourteen soil and weather factors, taken from the agrometeorological observatory located at instructional farm of Ramkrishna Ashram Krishi Vigyan Kendra, Nimpith and recorded from a nearby betelvine boroj, were subjected to multiple regression, binary logistic regression and canonical discriminant analysis to develop a suitable disease forewarning model. The binary logistic model, $\mathrm{Y}(0 / 1)=5.899+0.865\left(\mathrm{~T}_{\max }\right)-0.569(\mathrm{SM})+0.097\left(\mathrm{BRH}_{\min }\right) \mathrm{was}$ able to predict the disease risk with 78 per cent accuracy and correctly classified 94 per cent of cases during model validation in 2018. The weekly averages of maximum temperature $\left(\mathrm{T}_{\max }\right)$, soil moisture $(\mathrm{SM})$ and minimum relative humidity inside the boroj $\left(\mathrm{BRH}_{\text {min }}\right)$ were found to be the most significant predictors of disease incidence, in this model. The soil moisture at $69-72$ per cent of field capacity, minimum temperature of $25-27^{\circ} \mathrm{C}$, maximum temperature of $33-36^{\circ} \mathrm{C}$, average soil temperature of $28-30^{\circ} \mathrm{C}$, minimum relative humidity of $60-72$ per cent inside the boroj and maximum relative humidity of 83 - 89 per cent inside the boroj were found to be highly congenial for collar rot disease incidence in betelvine under coastal saline zone of West Bengal.
\end{abstract}

Key words: Betelvine, collar rot, prediction model, weather factors, soil moisture

Betelvine (Piper betle L.) is a dioecious, perennial creeper, grown in the tropical humid climate of South East Asia. Its heart shaped green leaves are not only used as mouth freshener and in medicine preparations, but also play an important role in rituals and customary practices. India is the leading producer and exporter of betel leaves in the world with 55 thousand ha area under cultivation (Guha, 2006). Among the Indian states, West Bengal alone shared $66 \%$ of the total country's production during 2014-15, engaging 5 lakh farm families (Anonymous, 2015). The humid and sub-tropical climate of the coastal saline zone of this State is congenial for growing the high quality Mitha pata variety of this crop that is exported to other states as well as to other countries for its low fibre content, sweet taste and fennel-like aroma (Balasubrahmanyam and Rawat, 1992).
The shade loving vines are mostly grown inside a protected chamber, known as "boroj", to provide a mild microclimate, conducive for the vegetative growth throughout the year (Sengupta, 2019). However, the same microclimate also aggravates several fungal and bacterial diseases, making the cultivation of this crop highly risky (Sengupta et al., 2011). Among various diseases, it is very difficult to manage and eradicate the collar rot disease, caused by the soil borne pathogen Sclerotium rolfsii Sacc, which is reported to cause $17-100 \%$ crop loss in West Bengal (Dasgupta et al., 2000; Garain et al., 2020).

Environmental factors play an important role in pathogen biology, its dissemination and expression of susceptibility or resistance of the host plant after infection (Bana et al., 2020). Though S. rolfsii is a soil borne fungi, infecting the collar region and roots of various crops, the environmental factors like temperature, relative 
humidity and rainfall play significant role on growth and development of the pathogen, as well as on disease incidence (Garibaldi et al., 2013).

As fresh betel leaves are consumed the application of fungicides may increase the chance of health hazards in the consumers. Fungicide application could be minimized by applying them only at times when conditions are conducive for disease development. Forecasting models that predict the likelihood of collar rot outbreak may provide important information for betelvine growers to execute a timely disease management plan. Moreover, when weather is not favourable for the disease, growers may avoid unnecessary fungicide applications, thereby reducing the monetary and environmental costs.

Disease prediction models have been successfully used to describe the relationship of physical and biological variables to components of disease epidemics (Ghosh et al., 2015; Wilbur et al., 2017). In the present investigation, attempts were made to understand the possibility of using weather factors, soil moisture and soil temperature with durations that allowed prediction of Sclerotium rolfsii induced collar rot incidence in betelvine before it actually occurred, using linear multiple regression analysis, logistic regression analysis and canonical discriminant analysis.

\section{MATERIALS AND METHODS}

An experiment was conducted from 2016 to 2018, within the betelvine boroj $\left(22^{\circ} 9^{\prime} 8.77^{\prime \prime} \mathrm{N}, 88^{\circ} 26^{\prime} 37.31\right.$ ”E) at instructional farm of Ramkrishna Ashram Krishi Vigyan Kendra (RAKVK), Nimpith, West Bengal.

\section{Collection of data on weather factors and soil temperature}

The daily weather data (temperature, relative humidity and rainfall) were collected from the agrometeorological observatory $\left(22^{\circ} 9^{\prime} 6.09^{\prime \prime} \mathrm{N}\right.$, $88^{\circ} 26^{\prime} 36.81^{\prime \prime}$ ) of RAKVK, located near the experiment site (Table 1). One set of soil thermometer, maximumminimum thermometer and drybulb-wetbulb thermometer (J. R. Mullick \& Co. Pvt. Ltd. make, as per IMD specification) were installed in the boroj to record the daily air temperature, soil temperature and humidity inside the boroj. The soil temperature was recorded at 5 $\mathrm{cm}$ depth, twice at 6:30 a.m. (considered as minimum soil temperature) and at 1:30 p.m. (considered as maximum soil temperature).

\section{Determination of soil moisture}

The soil moisture (SM) percentage in the betelvine boroj was calculated following gravimetric method, by the formula, $\mathrm{SM}=\left[\left(\mathrm{M}^{*} 100\right) / \mathrm{FC}\right]$, where $\mathrm{FC}$ and $\mathrm{M}$ denotes field capacity and soil moisture content, respectively. Field capacity (FC) of the soil of the betelvine boroj was calculated as $\mathrm{FC}=\left[\left(\mathrm{W}_{\mathrm{w}}-\mathrm{W}_{\mathrm{D}}\right)\right)^{* 100 /}$ $\left.\mathrm{W}_{\mathrm{D}}\right]$, where, $\mathrm{W}_{\mathrm{w}}$ and $\mathrm{W}_{\mathrm{D}}$ denotes weight of the saturated soil and dry soil, respectively (Romano and Santini, 2002). The soil moisture content (M) was calculated as $M$ $=\left[(\mathrm{W}-\mathrm{D})^{*} 100 / \mathrm{D}\right]$, where $\mathrm{W}$ and $\mathrm{D}$ represents the weight of wet soil and dry soil (dried in hot air oven at $105^{\circ} \mathrm{C}$ for $48 \mathrm{hrs}$ ), respectively. The soil moisture percentage was determined twice every week and finally expressed as weekly average. The field capacity was measured at quarterly interval, each after layering of new soil inside the boroj. Soil samples were collected at $0-15 \mathrm{~cm}$ depth for all the studies.

\section{Disease incidence (\%)}

The boroj was divided into three plots (replication). From each plot, 36 vines were marked randomly. The number of vines showing collar rot symptom was counted and percentage of disease incidence (DI) was calculated as:

Disease Incidence $(\%)=\frac{\text { No. of infected vines }}{\text { Total no. of vines assessed }} \times 100$

The disease incidence was noted at weekly interval, during 2016 to 2018.

\section{Analysis of data}

All the parameters were transformed into weekly average, except the weekly rainfall. The weekly disease incidence data were expressed as cumulative disease incidence (\%) and transformed into binomial values (' 1 ' was assigned for disease increment or 'disease' condition and ' 0 ' was assigned for absence of disease increment or 'no-disease' condition). Two-tailed Pearson correlation analysis was performed to determine the significant soil 
and weather factors for disease incidence.

To understand the possibility of using the weather and soil factors in predicting collar rot incidence before it actually occurred, stepwise multiple regression analysis (MRA), binary logistic regression analysis with forward conditional method (LRA) and canonical discriminant analysis with stepwise method (CDA) were employed. The first 104 weekly data (generated during 2016 and 2017) of the 15 parameters (collar rot incidence as dependent variable and fourteen weather and soil parameters as independent variables) were used for development of disease prediction model. All the statistical analysis was done using statistical software IBM SPSS 20.

\section{Model validation}

For validation of the models, the collar rot disease incidence was predicted by fitting the predictor variable of 2018 dataset into the respective models (equation) and comparing the values with the actual disease incidence during the same year.

\section{RESULTS AND DISCUSSION}

\section{Influence of soil and weather factors on collar rot incidence}

Among the fourteen different soil and weather variables studied, the maximum temperature $\left(\mathrm{T}_{\max }\right)$, minimum temperature $\left(\mathrm{T}_{\min }\right)$, maximum temperature inside boroj $\left(\mathrm{BT}_{\max }\right)$, minimum temperature inside boroj $\left(\mathrm{BT}_{\min }\right)$, maximum soil temperature $\left(\mathrm{ST}_{\max }\right)$, minimum soil temperature $\left(\mathrm{ST}_{\text {min }}\right)$ and average soil temperature $\left(\mathrm{ST}_{\text {avg }}\right)$ were found to be significantly and positively correlated $(\mathrm{p}<0.01)$ with the collar rot incidence (Table $1)$. The disease incidence was also positively correlated $(p<0.05)$ with the maximum relative humidity inside boroj $\left(\mathrm{BRH}_{\max }\right)$. Whereas, soil moisture $(\mathrm{p}<0.01)$ and rainfall $(p<0.05)$ were significantly and negatively correlated with collar rot incidence. This indicates that incidence of collar rot in betelvine increases with increase in temperatures at inside and outside the boroj, maximum \& minimum soil temperature and maximum relative humidity inside the boroj. This is in accordance with the previous findings, where $S$. rolfsii has been reported to incite severe disease outbreak in warm weather or summer months (Pinheiro et $a l ., 2010)$. However, both the increase in rainfall and soil moisture has limiting effect on the disease incidence.

\section{Multiple regression model}

Stepwise multiple regression analysis was done based on the two years data (2016 and 2017) for reducing the multicolinearity and finding the most critical contributors in the collar rot incidence which was selected based on the highest regression coefficient $\left(R_{a d j}{ }^{2}=0.42\right)$ and with the predictors having strong correlation with the disease incidence (equation "1" in Table 2). When the same model was validated with the separate data set generated during the year 2018, it could predict 56 per cent of disease incidence in comparison to the actual collar rot incidence in the same year.

The high value of root mean square error (RMSE $=1.115)$, found during the validation of the model (Fig. 1), indicated the necessity of a multivariate and non-parametric analysis for the development of a more accurate predictive model against the disease.

\section{Binary logistic regression model}

The binary logistic regression model (LRA) gave the probability of fresh disease occurrence $\left(\mathrm{Y}={ }^{\prime} 0\right.$ ' or ' 1 ') through a given set of covariate values (equation ' 2 ' in Table 2). For the binary model, disease was predicted to occur $(\mathrm{Y}=1)$ when the predicted probability exceeded a pre-specified cut-off value of 0.5 .

This model was statistically significant (high Nagelkerke $\mathrm{R}^{2}=0.79$ and $\chi^{2}=79.9, \mathrm{p}<0.001$ ), which accounted for 79 per cent of the variance in the dependent variable, i.e., "disease" or "no-disease" condition. According to this model, an increase in maximum temperature $\left(\mathrm{T}_{\max }\right)$ and minimum relative humidity inside boroj $\left(\mathrm{BRH}_{\min }\right)$ coupled with decrease in soil moisture (SM) increased the likelihood of occurrence of collar rot disease in betelvine.

The binary regression model developed with the 2016 and 2017 data was fit with the variables of 2018 data to predict the 'disease' or 'no-disease' condition. The model could predict 94 per cent of the cases correctly. The observed and predicted values of 'disease' or 'no-disease' condition are explained in Table 3. 
Table 1: Influence of weather and soil factors on collar rot disease incidence in betelvine

\begin{tabular}{|c|c|c|c|}
\hline \multirow[t]{2}{*}{ Factors } & \multirow{2}{*}{$\begin{array}{c}\text { Pearson correlation } \\
\text { coefficient with disease } \\
\text { incidence }\end{array}$} & \multicolumn{2}{|c|}{$\begin{array}{l}\text { Favourable condition for collar rot } \\
\text { incidence }\end{array}$} \\
\hline & & Minimum & Maximum \\
\hline Minimum temperature $\left(\mathrm{T}_{\min }\right)$ & $0.39 * *$ & $25.4^{\circ} \mathrm{C}$ & $27.2^{\circ} \mathrm{C}$ \\
\hline Maximum temperature $\left(\mathrm{T}_{\max }\right)$ & $0.50^{* *}$ & $32.5^{\circ} \mathrm{C}$ & $36.0^{\circ} \mathrm{C}$ \\
\hline Minimum relative humidity $\left(\mathrm{RH}_{\min }\right)$ & 0.09 & - & - \\
\hline Maximum relative humidity $\left(\mathrm{RH}_{\max }\right)$ & 0.19 & - & - \\
\hline Rainfall (RF) & $-0.21 *$ & - & - \\
\hline Minimum temperature inside boroj $\left(\mathrm{BT}_{\min }\right)$ & $0.39 * *$ & - & - \\
\hline Maximum temperature inside boroj $\left(\mathrm{BT}_{\max }\right)$ & $0.44 * *$ & - & - \\
\hline Minimum RH inside boroj $\left(\mathrm{BRH}_{\min }\right)$ & 0.12 & $60 \%$ & $72 \%$ \\
\hline Maximum RH inside boroj $\left(\mathrm{BRH}_{\max }\right)$ & $0.20^{*}$ & $83 \%$ & $89 \%$ \\
\hline Minimum soil temperature $\left(\mathrm{ST}_{\min }\right)$ & $0.39 * *$ & $26.7^{\circ} \mathrm{C}$ & $28.4^{\circ} \mathrm{C}$ \\
\hline Maximum soil temperature $\left(\mathrm{ST}_{\max }\right)$ & $0.42 * *$ & $29.6^{\circ} \mathrm{C}$ & $32.3^{\circ} \mathrm{C}$ \\
\hline Soil moisture (SM) & $-0.43 * *$ & $68.8 \%$ & $72.2 \%$ \\
\hline Average soil temperature $\left(\mathrm{ST}_{\text {avg }}\right)$ & $0.41 * *$ & $28.3^{\circ} \mathrm{C}$ & $30.2^{\circ} \mathrm{C}$ \\
\hline Average soil temperature $\mathrm{x}$ soil moisture $\left(\mathrm{SM} \mathrm{x} \mathrm{ST}_{\text {avg }}\right)$ & 0.12 & - & - \\
\hline
\end{tabular}

*Significant at $\mathrm{p}=0.05$ (2-tailed) $* *$ Significant at $\mathrm{p}=0.01$ (2-tailed)

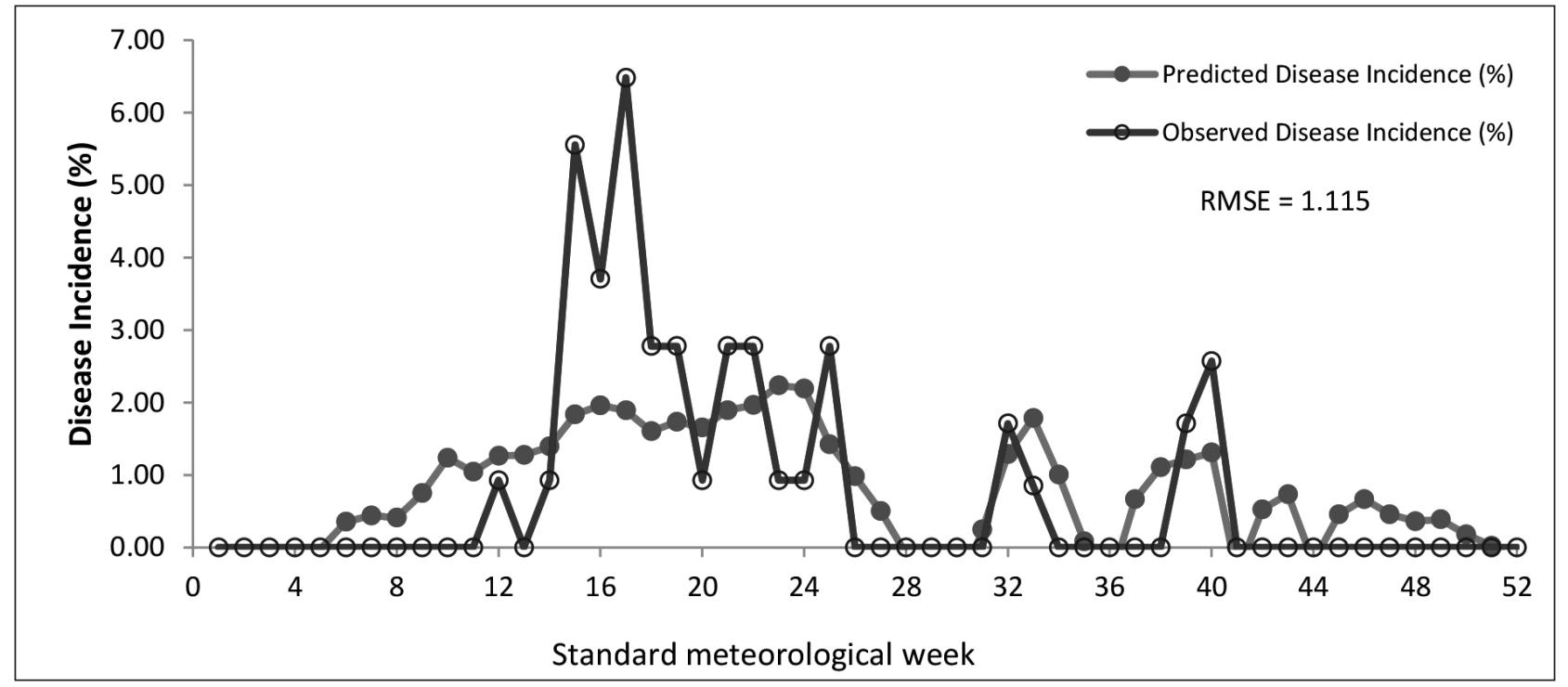

Fig. 1: Predicted and observed collar rot incidence graph based on 2018 data. The predicted values are derived from the stepwise multiple regression analysis model. RMSE = root mean square error

Disease prediction by logistic regression analysis has been tested extensively and proven effective in many plant pathogen systems, like Fusarium head blight epidemics in wheat (Shah et al., 2013), Sclerotinia sclerotiorum apothecial presence in soybean (Wilbur et al., 2017), etc. However, this is the first time that the binary logistic regression analysis is employed to predict $S$. rolfsii induced collar rot disease incidence in betelvine.

\section{Canonical discriminant function}

Among the fourteen weather variables and soil factors examined, two variable were found to be significant in predicting disease occurrence in the canonical discriminate function model viz., minimum temperature $\left(\mathrm{T}_{\text {min }}\right)$ and soil moisture (SM). The canonical discriminant function (equation ' 3 ' in Table 2) was statistically 
Table 2: Collar rot disease prediction models

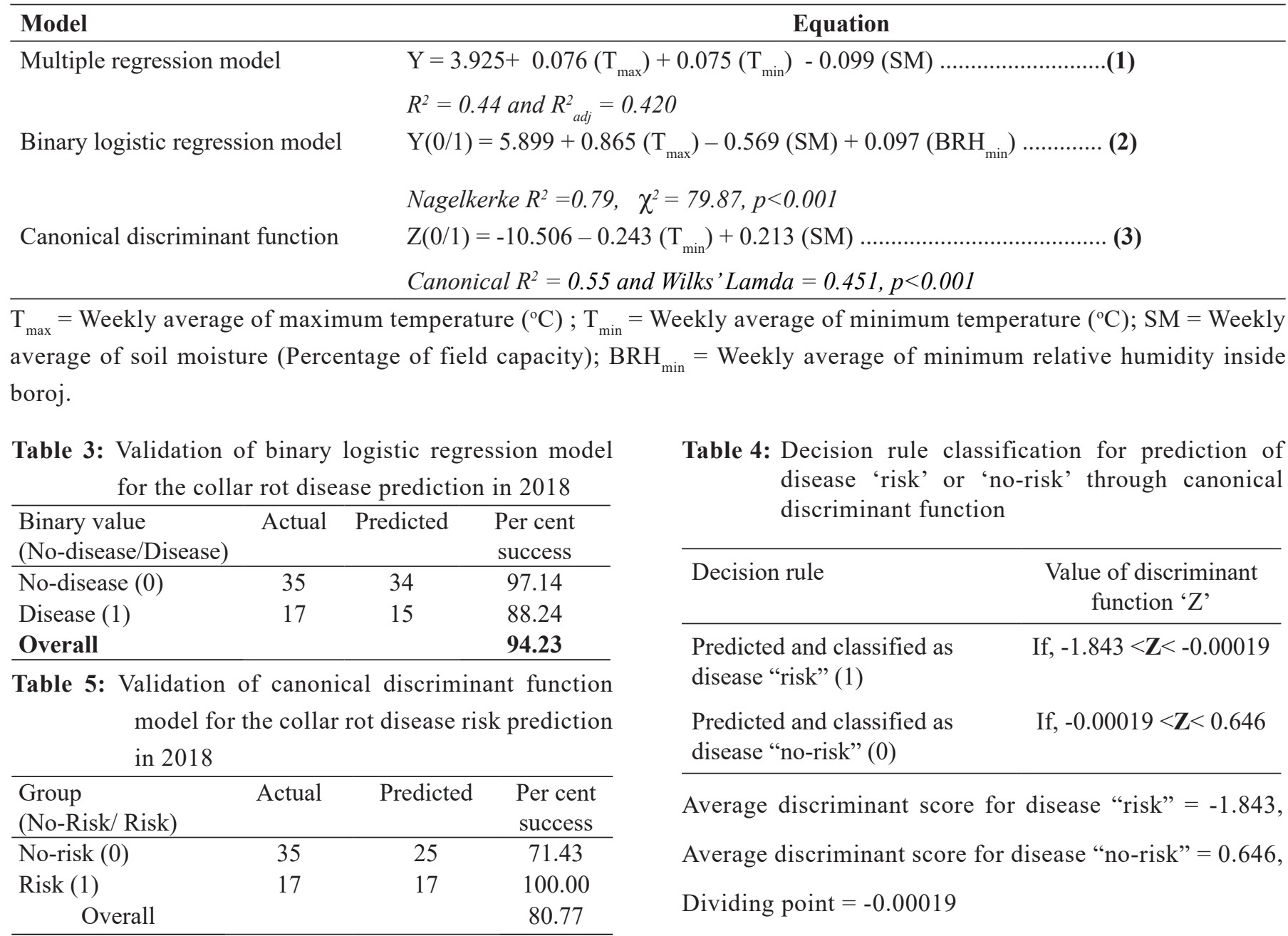

Table 6: Comparative performance of disease prediction models

\begin{tabular}{lcc}
\hline Disease Prediction Models & Goodness of fit statistics of the model & $\begin{array}{c}\% \text { of successful prediction during valida- } \\
\text { tion of model }\end{array}$ \\
\hline Multiple regression model & $\mathrm{R}^{2}{ }_{\text {adj }}=0.42$ & $55.77 \%$ \\
Binary logistic regression model & Nagelkerke $\mathrm{R}^{2}=0.79$ & $94.23 \%$ \\
Canonical discriminant function & Canonical $\mathrm{R}^{2}=0.55$ & $80.77 \%$ \\
\hline
\end{tabular}

significant (high canonical correlation of 0.741 at $\mathrm{p}<0.001$ and low Wilks' Lamda of 0.451 at $\mathrm{p}<0.001$ ) which could explain 55 per cent (squared canonical correlation) of the variance in disease incidence, i.e., disease "risk" $(\mathrm{Z}=1)$ or "no-risk" $(Z=0)$. From the function of the Group centroid, the average discriminant score of the two groups (disease "risk" and "no-risk") and the decision rule for their classification were derived (Table 4).

This model could successfully predict 81 per cent of disease "risk" or "no-risk", while used for validation in
2018 (Table 5).

\section{Comparative performance of the disease prediction} models

Among the three models, the binary logistic regression model performed better in predicting the disease risk over other models (Table 6). The significant predictors for $S$. rolfsii induced collar rot in betelvine are 'maximum air temperature', 'soil moisture' and 'minimum relative humidity inside the boroj'. 
Favourable ranges of weather and soil factors for collar rot disease incidence

From the group statistics during canonical discriminant analysis, a soil moisture level of $69-72$ per cent of field capacity, minimum temperature of 25 $27^{\circ} \mathrm{C}$, maximum temperature of $33-36^{\circ} \mathrm{C}$, average soil temperature of $28-30^{\circ} \mathrm{C}$, minimum $\mathrm{RH}$ of $60-72$ per cent inside boroj and maximum RH of 83 - 89 per cent inside boroj were found to be highly congenial for collar rot incidence in betelvine under coastal saline zone of West Bengal (Table 1). The earlier reports on the optimum temperature of $30^{\circ} \mathrm{C}$ for the maximum germination of sclerotia and mycelial growth in $S$. rolfsii justify the present findings (Maji et al., 2019). The soil moisture level also plays important role in survival of the sclerotia, its germination and mycelial growth of the pathogen. Increase in soil moisture has been reported to decreases the viability of the sclerotia of $S$. rolfsii (Raghavendra et al., 2018).

\section{CONCLUSION}

The S. rolfsii induced collar rot disease in betelvine was found to be significantly and positively correlated with the temperature and relative humidity but negatively correlated with soil moisture and rainfall. The binary logistic regression model performed better in predicting the disease risk over the multiple regression model and canonical discriminant function. An increase in maximum temperature and minimum relative humidity inside the boroj, coupled with a decrease in soil moisture increases the likelihood of occurrence of the disease. The binary logistic model, thus developed, may in future be used in prediction of collar rot disease incidence in betelvine, for its timely management. The findings on the favourable ranges of weather and soil factors for the disease epidemiology will be useful to decide on adoption of some cultural practices like irrigation and mulching for the eco-friendly management of the disease.

Conflict of Interest Statement: The author(s) declare(s) that there is no conflict of interest.

Disclaimer: The contents, opinions, and views expressed in the research article published in the Journal of Agrometeorology are the views of the authors and do not necessarily reflect the views of the organizations they belong to.

Publisher's Note: The periodical remains neutral with regard to jurisdictional claims in published maps and institutional affiliations.

\section{REFERENCES}

Anonymous (2015). Chaya Ghore Paan Chas. Directorate of Horticulture, Department of Food Processing Industries and Horticulture, Government of West Bengal, 2014-15.

Balasubrahmanyam, V. R. and Rawat, A. K. S. (1992). Flavour characteristics of Piper betle L. J. Spices Aromat. Crops., 1(1): 30-38.

Bana, J. K., Choudhary, J. S., Ghoghari, P. D., Sharma, H., Kumar, S. and Patil, S. J. (2020). Influence of weather parameters on powdery mildew of mango inflorescence in humid tropics of South Gujarat. J. Agrometeorol., 22(4): 488-493

Dasgupta, B., Roy, J. K., and Sen, C. (2000). Two major fungal diseases of betelvine. In: M. K. Dasgupta (ed.). Diseases of Plantation Crops, Spices, Betel vine and Mulberry, pp. 133-137.

Garain, P. K., Mondal, B., Maji, A. and Dutta, S. (2020). Survey of Major Diseases in Mitha Pata variety of Betelvine (Piper betle L.) under Coastal Saline Zone of West Bengal, India. Int. J. Curr. Microbiol. App. Sci., 9(03): 2490-2498.

Garibaldi, A., Gilardi, G., Ortu, G., Gullino, M. L. and Testa, M. (2013). First report of southern blight caused by Sclerotium rolfsii on common bean (Phaseolus vulgaris) in Italy. Plant Dis., 9: $7-10$.

Ghosh, D., Bhattacharya, I., Dutta, S., Saha, A. and Mazumdar, D. (2015). Dependence of the weather on outbreak of cucumber downy mildew (Pseudoperonospora cubensis) in eastern India. J. Agrometeorol., 17(1): 43-50. 
Guha, P. (2006). Betel Leaf: The Neglected Green Gold of India. J. Hum. Ecol., 19(2): 87-93.

Maji, A., Nath, R., Singh, D. and Garain, P. K. (2019). Effect of variability and edaphological characteristics on growth of Sclerotium rolfsii (Sacc.) causing collar rot disease of sunflower in coastal region of West Bengal, India. Legum. Res., 42(5): 705-709.

Pinheiro, V. R., Seixas, C., Godoy, C. V., Soares, R. M., Oliveira, M. C. N. and Almeida, A. M. R. (2010). Development of Sclerotium rolfsii sclerotia on soybean, corn, and wheat straw, under different soil temperatures and moisture contents. Pesq. agropec. bras., 45(3): 332-334.

Raghavendra, B., Srinivas, T. and Padmodaya, B. (2018). Influence of Soil $\mathrm{pH}$ and Moisture on Viability of Sclerotia of S. rolfsii. Int. J. Curr. Microbiol. App. Sci., 7(8): 92-100.

Romano, N. and Santini, A. (2002). Water retention and storage: Field. In: J. H. Dane and G.C. Topp (Eds.) Methods of Soil Analysis, Part 4, Physical Methods, SSSA Book Series N.5, Madison, WI,
USA, pp. 721-738.

Sengupta, D. K., Dasgupta, A. B. and Datta, P. (2011). Management of foot rot of betel vine (Piper betle L.) caused by Phytophthora parasitica Dastur. $J$. Crop. Weed, 7(2):179-183.

Sengupta, K. (2019). Agronomy of Betelvine Crop. In: M. Hasanuzzaman (ed.) Agronomic Crops. Springer, Singapore, pp. 533-543.

Shah, D. A., Molineros, J. E., Paul, P. A., Willyerd, K. T., Madden, L. V. and De Wolf, E. D. (2013). Predicting Fusarium head blight epidemics with weather-driven pre-and postanthesis logistic regression models. Phytopathol., 103: 906-919.

Wilbur, J. F., Fall, M. L., Bloomingdale, C., Byrne, A. M., Chapman, S. A., Isard, S. A., Magarey, R. D., McCaghey, M. M., Mueller, B. D., Russo, J. M., Schlegel, J., Chilvers, M. I., Mueller, D. S., Kabbage, M. and Smith, D. L. (2017). Weatherbased models for assessing the risk of Sclerotinia sclerotiorum apothecial presence in soybean (Glycine max) fields. Plant Dis., 102(1): 73-84. 